\title{
PENGEMBANGAN PERANGKAT PEMBELAJARAN UNTUK MENIGKATKAN KEMAMPUAN BERPIKIR KREATIF MATEMATIS SISWA MENGGUNAKAN MODEL DISCOVERY LEARNING
}

\author{
Welni Julitra Damanik*, Edi Syahputra \\ Program Studi Pendidikan Matematika, FMIPA, Universitas Negeri Medan, \\ Jl. Willem Iskandar Psr. V Medan Estate, Medan, Indonesia, 20221 \\ *Email : welnidamanik@gmail.com
}

\begin{abstract}
ABSTRAK
Penelitian ini bertujuan untuk: (1) mendeskripsikan keefektifan perangkat pembelajaran yang dikembangkan berbasis model discovery learning; (2) mendeskripsikan peningkatan kemampuan berpikir kreatif matematis siswa yang diberi pembelajaran berbasis model discovery learning menggunakan perangkat yang dikembangkan, (3) menemukan perangkat pembelajaran yang efektif dalam meningkatkan kemampuan berpikir kreatif matematis siswa. Jenis penelitian yang digunakan adalah penelitian pengembangan yang mengacu pada model Thiagarajan, Semmel dan Semmel yaitu model 4-D (define, design, develop dan disseminate). Subjek penelitian ini adalah siswa kelas VII-I pada Uji Coba I dan siswa kelas VII-E pada Uji Coba II SMP Negeri 6 Medan. Instrumen penelitian yang digunakan adalah lembar penilaian RPP dan LAS untuk mengukur kevalidan, tes kemampuan pemahaman konsep, angket respon siswa dan lembar observasi keterlaksanaan pembelajaran. Hasil penelitian menunjukkan bahwa: kualitas kevalidan perangkat pembelajaran memenuhi kriteria valid berdasarkan skor rata-rata RPP yaitu 4,25 dari skor maksimal 5,00 dengan kriteria Baik dan skor rata-rata LAS yaitu 4,18 dari skor maksimal 5,00 dengan kriteria baik; perangkat pembelajaran yang dikembangkan telah memenuhi kriteria keefektifan dengan: a) ketuntasan belajar secara klasikal telah melebihi batas minimal yaitu pada uji coba II sebesar 87\%, b) ketercapaian indikator/ketuntasan tujuan pembelajaran telah tercapai untuk setiap indikator pada uji coba II, c) Kualitas kepraktisan perangkat pembelajaran memenuhi kriteria praktis berdasarkan skor rata-rata angket respon siswa 3,95 dari maksimal 5,00 pada uji coba I dan 4,0 dari 5,00 pada uji coba II. Keterlaksanaan kegiatan pembelajaran yaitu 88,7\% pada uji coba I dan 93\% pada uji coba II. d) waktu pembelajaran tidak melebihi pembelajaran biasa yaitu waktu sama dengan pembelajaran biasa pada uji coba I dan uji coba II; kemampuan berpikir kreatif matematis siswa mengalami peningkatan yaitu nilai rata-rata kemampuan pemahaman konsep pada uji coba I sebesar 70,1 meningkat sebesar 11,3 menjadi 81,4 pada uji coba II dan banyak siswa yang tuntas pada uji coba I 70\% meningkat sebesar 16,6\% menjadi 86,7\% pada uji coba II.
\end{abstract}

Kata kunci : perangkat pembelajaran, discovery learning, kemampuan berpikir kreatif.

Pendidikan memberikan kemungkinan pada siswa untuk memperoleh "kesempatan", "harapan", dan pengetahuan agar dapat hidup secara lebih baik. Besarnya kesempatan dan harapan sangat bergantung pada kualitas pendidikan yang ditempuh. Pendidikan juga dapat menjadi kekuatan untuk melakukan perubahan agar sebuah kondisi menjadi lebih baik. Pendidikan yang berkualitas tentunya melibatkan siswa untuk aktif belajar dan mengarahkan terbentuknya nilai-nilai yang dibutuhkan oleh siswa dalam menempuh kehidupan (Surya, Putri dan Mukhtar, 2017)

Welni Julitra Damanik, Edi Syahputra. Pengembangan Perangkat Pembelajaran untuk Menigkatkan Kemampuan Berpikir Kreatif Matematis Siswa Menggunakan Model Discovery Learning. Jurnal Inspiratif, Vol. 4, No. 1 April 2018. 
Proses pembelajaran dalam satuan pendidikan diselenggarakan secara interaktif, inspiratif, menyenangkan, menantang, memotivasi peserta didik untuk berpartisipasi aktif, serta memberikan ruang yang cukup bagi prakarsa, kreativitas, dan kemandirian sesuai dengan bakat, minat, dan perkembangan fisik serta psikologi peserta didik. Untuk itu, setiap satuan pendidikan perlu melakukan perencanaan pembelajaran, pelaksanaan proses pembelajaran serta peniaian proses pembelajaran untuk meningkatkan efisiensi dan efektivitas ketercapaian kompetensi lulusan. Dalam kegiatan pembelajaran struktur penyampaian informasi perlu dipersiapkan secara matang. Agar proses pembelajaran di kelas berlangsung optimal maka kegiatan belajar siswa perlu dirancang oleh guru, karena hasil rancangan berpengaruh terhadap kemampuan siswa. Hal ini didukung oleh (Kurniawan, 2013) yang mengatakan : "Tingkat keberhasilan pelaksanaan suatu proses pembelajaran dipengaruhi oleh banyak faktor, diantaranya perbedaan kemampuan peserta didik dan proses pembelajaran. Sebagaimana diketahui bahwa setiap peserta didik mempunyai kemampuan yang berbeda-beda. Ada yang memiliki kemampuan tinggi dan ada yang berkemampuan sedang ataupun rendah. Oleh karena itu, untuk mengakomodasi dan mengapresiasi perbedaan individual peserta didik dalam pebelajaran dalam rangka mengoptimalkan prestasi belajar dibutuhkan cara atau pendekatan yang dapat diterapkan untuk menyesuaikan pembelajaran dengan perbedaan kemampuan peserta didik."

Dengan demikian pembelajaran merupakan pengaturan pengalaman siswa yang disengaja untuk memperoleh kemampuan tertentu. Kemampuan tersebut bervariasi secara kualitatif mulai dari mengingat sampai menemukan pengetahuan baru, tergantung kepada guru dalam mengembangkan strategi belajar.

Kemampuan guru dalam mengelola pembelajaran di kelas terkait dengan profesi guru sebagai tenaga pendidik, mengharuskan guru untuk mengembangkan kemampuan diri baik dari segi ilmu maupun kemampuan pedagogiknya. Menurut Kemendikbud
(2014) beberapa kegiatan yang dapat dilakukan guru untuk pengembangan diri antara lain : (1) penyusunan RPP, program kerja, dan/atau perencanaan pendidikan; (2) penyusunan kurikulum dan bahan ajar; (3) pengembangan metodologi mengajar; (4) penilaian proses dan hasil pembelajaran peserta didik; (5) penggunaan dan pengembangan teknologi informatika dan komputer (TIK) dalam pembelajaran ; dan (6) inovasi proses pembelajaran.

Kemampuan guru dalam menyusun perangkat pembelajaran yang sesuai dengan tujuan pendidikan menjadi paradigma bahwa perangkat pembelajaran adalah kumpulan berkas-berkas dalam memenuhi kelengkapan administrasi di sekolah. Guru belum memanfaatkan perangkat pembelajaran sebagaimana mestinya. Bahkan, menurut Akbar (2013) dalam (Wasriono, 2015) mengemukakan bahwa: "Dari hasil KKG (Kelompok Keja Guru) dan MGMP (Musyawarah Guru Mata Pelajaran) yang seragam antara satu dengan sekolah lain, guru cenderung hanya sekedar copy paste perangkat pembelajaran mulai silabus, rencana pelaksanaan pembelajaran (RPP), format penilaian, dan lain sebagainya, walaupun kondisi dan kemampuan siswa yang diajarkan di setiap sekolah berbedabeda"

Permasalahan guru dalam menggunakan perangkat pembelajaran juga ditemukan di SMP Negeri 6 Medan. Dari hasil pengamatan yang dilakukan peneliti di SMP Negeri 6 Medan, ditemukan bahwa sebagian guru masih membuat perangkat pembelajaran hanya untuk kelengkapan administrasi sekolah saja, tidak untuk membantunya dalam proses pembelajaran di kelas. Hal ini didukung dengan hasil wawancara peneliti dengan salah satu guru matematika di SMP N 6 Medan yaitu Bu Napitupulu, ibu Napitupulu mengatakan bahwa RPP miliknya diawal semester telah diserahkan kepada kepala sekolah dan beliau tidak memiliki salinannya.

Berdasarkan hasil angket yang telah dibagikan oleh peneliti kepada siswa SMP Negeri 6 Medan kelas VII-E, mereka beranggapan bahwa pembelajaran yang berlangsung di kelas masih sulit dipahami

Welni Julitra Damanik, Edi Syahputra. Pengembangan Perangkat Pembelajaran untuk Menigkatkan Kemampuan Berpikir Kreatif Matematis Siswa Menggunakan Model Discovery Learning. Jurnal Inspiratif, Vol. 4, No. 1 April 2018. 
dan membosankan. Dalam kegiatan pembelajaran, yang dilakukan siswa hanya mendengarkan penjelasan dari guru, mencatat kemudian mengerjakan soal-soal. Hal ini tidak sejalan dengan proses pembelajaran yang diterapkan pada kurikulum 2013, yakni pembelajaran yang berpusat pada siswa (student centered). Pembelajaran yang berlangsung masih pembelajaran yang berpusat pada guru (theacher centered).

Dalam mengajar guru cenderung test book oriented, hanya memberikan pengetahuan, informasi yang diikuti dengan pemberian contoh soal yang sama dengan yang di buku. Siswa hanya disuapi dengan konsep-konsep dari guru yang membuat siswa tidak dapat mengekspresikan pemahamannya dan merasa jenuh. Hal ini didukung oleh pendapat Arends (Trianto 2010:7) "It is strange that we expect students to learn yet seldom teach then about learning, we expect student to solve problems yet seldom teach then about problem solving" yang berarti dalam mengajar guru selalu menuntut siswa untuk belajar dan jarang memberikan pelajaran tentang bagaimana siswa untuk belajar, guru juga menuntut siswa untuk menyelesaikan masalah dan jarang mengajarkan bagaimana siswa seharusnya menyelesaikan masalah. Surya dan Syahputra (2017 mengemukakan bahwa kegagalan dalam matematika sekolah sebagian besar terkait dengan tradisi pengajaran yang tidak sesuai dengan cara kebanyakan siswa belajar. Metode pengajaran matematika tradisional telah ditemukan sangat cacat dan penuh dengan banyak kekurangan yang tidak memungkinkan siswa untuk secara aktif membangun pengetahuan matematika mereka sendiri.

Cara guru mengajar yang masih bersifat monoton masih membuat siswa beranggapan bahwa matematika itu sulit untuk dimengerti, tidak menarik dan lebih mengkhawatirkan lagi adalah matematika sudah merupakan suatu subjek yang dihindari oleh siswa dan kondisi seperti ini akan mengakibatkan siswa kesulitan untuk menguasai pelajaran matematika dan sangat berpengaruh terhadap kemampuan berpikir matematis siswa tersebut.

Hal ini dikuatkan juga dengan hasil angket siswa yang diberikan peneliti di kelas VII SMP Negeri 6 Medan yang menyatakan bahwa siswa merasa jenuh dan sulit memahami materi pelajaran dengan pendekatan yang dilakukan oleh gurunya yang setiap pertemuan hanya mengunakan metode ceramah, latihan dan mengerjakan soal-soal dan sesekali berdiskusi. Hal ini juga berpengaruh terhadap minat belajar siswa terhadap matematika, berdasarkan angket yang dibagikan peneliti dari 33 siswa yang mengisi angket hanya terdapat lima siswa yang menyukai pelajaran matematika dan selebihnya tidak menyukai matematika. Mereka beranggapan bahwa pelajaran matematika sulit dan kurang menarik.

Hakekat tujuan pembelajaran matematika di sekolah adalah mempersiapkan siswa agar mampu menghadapi perubahan keadaan di dalam kehidupan dunia yang selalu berkembang. Siswa dituntut agar mampu menghadapi setiap perubahan yang terjadi dengan terampil dan kreatif. Dalam mempelajari matematika siswa juga dituntut memiliki keterampilan dan kemampuan berpikir kreatif dalam memecahkan suatu masalah.

Kemampuan berpikir kreatif sangat penting dalam memecahkan masalah-masalah matematika. Tidak hanya memecahkan masalah, kemampuan berpikir kreatif juga sangat penting digunakan dalam menemukan konsep-konsep matematika. Pentingnya berpikir kreatif diungkapkan Zimmer dalam (Ismayati,2015) yang menyatakan bahwa ; "Kreativitas adalah kemampuan untuk mengembangkan ide-ide baru dan menemukan cara-cara baru dalam melihat masalah dan peluang. Kemampuan berpikir kreatif sangat diperlukan agar kompetensi sumber daya manusia kita tidak kalah dengan bangsa lain."

Berpikir kreatif adalah proses berpikir yang memiliki ciri-ciri kelancaran (fluency), keluwesan (flexibility), Keaslian (originality). Kelancaran adalah kemampuan mengeluarkan ide atau gagasan sebanyak mungkin secara jelas. Keluwesan adalah kemampuan mengeluarkan ide atau gagasan

Welni Julitra Damanik, Edi Syahputra. Pengembangan Perangkat Pembelajaran untuk Menigkatkan Kemampuan Berpikir Kreatif Matematis Siswa Menggunakan Model Discovery Learning. Jurnal Inspiratif, Vol. 4, No. 1 April 2018. 
yang beragam dan tidak monoton dengan melihat dari berbagai sudut pandang. Oariginality adalah kemampuan untuk mengeluarkan ide atau gagasan yang unik dan tidak biasanya, misalnya yang berbeda dari yang ada di buku atau berbeda dari pendapat orang lain. Elaborasi adalah kemampuan untuk menjelaskan faktor-faktor yang mempengaruhi dan menambah detail dari ide atau gagasannya sehingga lebih bernilai (Ismayati, 2015).

Kemampuan berpikir kreatif sangat diperlukan dalam semua pengembangan materi dari semua pembelajaran yang diajarkan di kelas, terutama dalam pelajaran matematika. Karena kemampuan berpikir kreatif dapat digunakan untuk memecahkan masalah matematika dengan berbagai cara penyelesaian. Hal ini dikukung oleh Moma (2015:29) yang mengatakan: "Berpikir kreatif adalah aktivitas mental yang terkait dengan kepekaan terhadap suatu masalah, mempertimbangkan informasi baru dan ideide yang tidak biasanya dengan suatu pikiran terbuka, serta dapat membuat hubunganhubungan dalam menyelesaikan masalah."

Dengan memiliki kemampuan berpikir kreatif, siswa akan lebih mudah untuk memecahkan masalah-masalah matematika. Rendahnya kreativitas dalam pemecahan masalah di atas menunjukkan bahwa kurangnya pemahaman siswa terhadap materi ajar sehingga tidak bisa menghasilkan alternatif penyelesaian untuk memecahkan masalah. Hal ini dapat disebabkan oleh desain perangkat pembelajaran yang dirancang atau yang diterapkan guru belum relevan terhadap tujuan pembelajarannya.

Karakter siswa yang paling melemahkan adalah motivasi siswa yang rendah untuk belajar. Sebagian besar motivasi siswa masih sekedar lulus SMA, hanya sebagian kecil yang bercita-cita melanjut ke perguruan tinggi. Hal ini menyebabkan aktivitas siswa dalam belajar juga hanya sebatas menyelesaikan tugas rutin seorang siswa. Hal ini menurut siswa karena keterbatasan ekonomi keluarga (Surya, 2013)
Suatu pembelajaran dirancang bertujuan untuk memperbaiki dan meningkatkan kualitas pembelajaran. Ini dilakukan dengan memilih, dan mengembangkan model pembelajaran yang optimal untuk mencapai hasil pembelajaran yang diinginkan. Model pemebelajaran discovery learning dipilih peneliti yang dianggap mampu meningkatkan kemampuan berpikir kreatif matematis siswa.

Sesuai dengan implementasi kurikulum 2013 yang melibatkan siswa secara aktif dalam pembelajaran, model Discovery learning dianggap mampu mengubah pembelajaran yang teacher centered (pembelajaran berpusat pada guru) menjadi pembelajara yang student centered (pembelajaran berpusat pada siswa). Dalam mengaplikasikan model pembelajaran discovery learning guru berperan sebagai pembimbing dengan memberikan kesempatan kepada siswa untuk belajar secara aktif dan mengarahkan kegiatan belajar siswa sesuai dengan tujuan. Hal ini sesuai dengan karakteristik discovery learning yang dikemukakan Hosnan (2014:284); "Ciri utama belajar menemukan, yaitu (1) mengeksplorasi dan memecahkan masalah untuk menciptakan, menggabungkan dan menggeneralisasi pengetahuan; (2) berpusat pada siswa; (3) kegiatan untuk menggabungkan pengetahuan baru dan pengetahuan yang sudah ada".

Dalam mengaplikasikan model pembelajaran discovery learning guru berperan sebagai pembimbing dengan memberikan kesempatan kepada siswa untuk belajar secara aktif dan mengarahkan kegiatan belajar siswa sesuai dengan tujuan. Dengan demikian kegiatan pembelajaran berpusat pada siswa (student oriented) bukan lagi berpusat pada guru (teacher oriented).

Dengan menggunakan model discovery learning dalam pembelajaran dapat meningkatkan kemampuan berpikir kreatif matematis siswa karena serangkaian kegiatan dalam proses discovery learning merupakan aktifitas yang dapat mencapai indikator-indikator kemampuan berpikir kreatif matematis. Disamping itu model

Welni Julitra Damanik, Edi Syahputra. Pengembangan Perangkat Pembelajaran untuk Menigkatkan Kemampuan Berpikir Kreatif Matematis Siswa Menggunakan Model Discovery Learning. Jurnal Inspiratif, Vol. 4, No. 1 April 2018. 
pembelajaran yang sesuai tersebut hendaknya diimplementasikan dalam perangkat pembelajaran agar mendapatkan sumber belajar yang baik, sehingga mampu mengusai masalah yang disebutkan diatas.
Dimana perangkat pembelajaran yang akan dikembangkan menggunakan model pembelajaran discovery learning adalah Rencana Pelaksanaan Pembelajaran (RPP) dan Lembar Kerja Siswa (LKS)

\section{METODE PENELITIAN}

Penelitian ini merupakan penelitian pengembangan (research and development $/ R \& D$ ) yaitu penelitian yang menghasilkan produk tertentu serta menguji keefektifan produk tersebut (Sugiono, 2015: 407). Model pengembangan perangkat pembelajaran menggunakan model Thiagarajan, dkk yaitu model 4-D (define, design, develop, disseminate). Dalam penelitian ini akan dihasilkan produk pengembangan adalah perangkat pembelajaran matematika dengan model discovery learning pada materi Segiempat berupa Rencana Pelaksanaan Pembelajaran (RPP) dan Lembar Kerja Siswa (LKS). Sedangkan instrumen yang digunakan adalah tes kemampuan pemahaman konsep, lembar observasi keterlaksanaan pembelajaran, dan angket respon siswa dan guru.

Subjek dalam penelitian ini adalah sebanyak 35 orang siswa kelas VII-I sebagai uji coba I dan sebanyak 34 orang siswa kelas VII-E uji coba II, sedangkan objek dalam penelitian ini adalah perangkat pembelajaran berupa Rencana Pelaksanaan Pembelajaran (RPP) dan Lembar Kerja Siswa (LKS) berbasis model discovery learning materi segiempat.

Penelitian ini menggunakan prosedur dan rancangan penelitian pengembangan. Prosedur pengembangan dilakukan merujuk pada model pengembangan 4-D (Four D) yang merupakan model pengembangan perangkat pembelajaran. Model ini dikembangkan oleh S.Thiagarajan, Dorothy S.Semmel, dan Melvyn I. Semmel (Trianto, 2011: 189). Model ini terdiri dari 4 tahap pengembangan yaitu define (pendefenisian), design (perancangan), develop (pengembangan), dan desseminate (penyebaran). Dalam pengembangan ini digunakanan model 4-D yang dimodifikasi menjadi 3-D karena jika tahap ketiga telah dilaksanakan sudah diperoleh perangkat yang baik sehingga tujuan pengembangan telah dipenuhi.

Pada prinsipnya meneliti adalah melakukan pengukuran, maka harus ada alat ukur yang baik. Alat ukur dalam penelitian biasanya dinamakan instrumen penelitian (Sugiono, 2015: 148). Instrumen dalam penelitian ini akan digunakan untuk mengukur kevalidan dan keefektifan. Instrumen yang digunakan adalah lembar validasi ahli, angket respon siswa dan guru, tes pemahaman konsep serta lembar observasi keterlaksanaan pembelajaran. Lembar validasi ahli digunakan untuk mengukur kriteria kevalidan, tes pemahaman konsep dan angket respon siswa dan guru digunakan untuk mengukur kriteria keefektifan perangkat pembelajaran yang dikembangkan dengan model discovery learning.

Teknik analisis data merupakan teknik yang digunakan untuk menganalisis data yang didapatkan dalam proses penelitian. Tujuan dilakukan analisis data adalah untuk mengetahui kevalidan dan keefektifan perangkat pembelajaran dengan model discovery learnin.

Kevalidan perangkat pembelajaran diperoleh berdasarkan hasil analisis data lembar penilaian perangkat pembelajaran dosen ahli dan guru matematika. Analisis kevalidan dilakukan sebagai berikut:

1) Tabulasi data skor hasil penilaian perangkat pembelajaran dengan mengelompokkan butir-butir pertanyaan yang sesuai dengan aspek-aspek yang diamati. Tabel 1 berikut ini merupakan

Welni Julitra Damanik, Edi Syahputra. Pengembangan Perangkat Pembelajaran untuk Menigkatkan Kemampuan Berpikir Kreatif Matematis Siswa Menggunakan Model Discovery Learning. Jurnal Inspiratif, Vol. 4, No. 1 April 2018. 
pedoman penskoran terhadap hasil penilaian menggunakan skala Likert 1-5.

Tabel 1 Pedoman Penskoran terhadap Hasil Penilaian

\begin{tabular}{|l|c|}
\hline Kriteria & Skor \\
\hline Sangat Baik & 5 \\
\hline Baik & 4 \\
\hline Cukup & 3 \\
\hline Kurang & 2 \\
\hline Sangat Kurang & 1 \\
\hline
\end{tabular}

2) Menghitung rata-rata skor tiap aspek dengan menggunakan formula : $\bar{x}=\frac{\sum_{i=1}^{n} x_{i}}{n}$

Keterangan:

$\bar{x}=$ rerata skor

$x_{i}=$ skor keterangan ke-i

$n=$ banyaknya butir pernyataan

tiap aspek

3) Mengkonversi skor rerata setiap aspek penilaian menjadi nilai kualitatif berdasarkan kriteria penilaian skala 5 menurut Widoyoko (2009:238) yang tercantum dalam tabel 3.2 berikut:

Tabel 2. Pedoman Kriteria Kevalidan

\begin{tabular}{|c|l|}
\hline Interval Skor & Kriteria \\
\hline $\bar{x}>4,2$ & Sangat Baik \\
\hline $3,4<\bar{x} \leq 4,2$ & Baik \\
\hline $2,6<\bar{x} \leq 3,4$ & Cukup \\
\hline $1,8<\bar{x} \leq 2,6$ & Kurang \\
\hline $\bar{x} \leq 1,8$ & Sangat Kurang \\
\hline
\end{tabular}

Berdasarkan tabel 2 akan diperoleh kualifikasi kevalidan perangkat pembelajaran yang dikembangkan. Perangkat pembelajaran dikatakan valid jika minimal kualifikasi tingkat kevalidan yang diperoleh adalah baik.

a. Data kepraktisan perangkat pembelajaran diperoleh dari angket respon siswa dan lembar observasi keterlaksanaan pembelajaran.

b. Analisis kepraktisan angket respon siswa dan lembar observasi keterlaksanaaan pembelajaran

Analisis kepraktisan perangkat pembelajaran menggunakan angket respon siswa dan lembar observasi keterlaksanaan pembelajaran, Analisis angket respon siswa dapat dilakukan dengan cara berikut:

1) Tabulasi data skor hasil angket respon siswa dengan mengelompokkan butir-butir pernyataan sesuai dengan aspek-aspek yang diamati. Tabel 3 berikut merupakan pedoman penskoran angket respon siswa menggunakan skala likert 15.

Tabel 3. Pedoman Penskoran Angket Respon Siswa

\begin{tabular}{|l|l|l|}
\hline \multirow{2}{*}{ Kategori } & \multicolumn{2}{|l|}{ Skor Pernyataan } \\
\cline { 2 - 3 } & Positif & Negatif \\
\hline Sangat Setuju (SS) & 5 & 1 \\
\hline Setuju (S) & 4 & 2 \\
\hline Netral (N) & 3 & 3 \\
\hline Tidak Setuju (TS) & 2 & 4 \\
\hline Sangat Tidak Setuju (STS) & 1 & 5 \\
\hline
\end{tabular}

2) Menghitung rata-rata skor tiap aspek dengan menggunakan formula :

$$
\bar{x}=\frac{\sum_{i=1}^{n} x_{i}}{n}
$$

Keterangan:

$\bar{x}=$ rerata skor

$x_{i}=$ skor keterangan ke-i

$n=$ banyaknya butir pernyataan tiap aspek

3) Mengkonversi skor rerata setiap aspek penilaian menjadi nilai kualitatif berdasarkan kriteria penilaian skala 5 menurut Widoyoko (2009:238) seperti yang tercantum dalam tabel 3.3 di atas sehingga diperoleh kualifikasi perangkat pembelajaran yang telah dikembangkan berdasarkan tabel 3.4 di atas. Perangkat pembelajaran dikatakan praktis jika minimal kualifikasi tingkat kepraktisan yang diperoleh adalah baik.

Berikut merupakan langkah analisis lembar observasi keterlaksanaan pembelajaran.

a. Menghitung banyaknya observer memilih pilihan "ya" pada aspek yang diamati dalam lembar observasi keterlaksanaan pembelajaran untuk setiap pertemuan.

b. Menghitung persentase jumlah yang didapat pada langkah sebelumnya menggunakan rumus sebagai berikut. $\%$

$$
=\frac{\text { banyak jawaban " } Y a "}{\text { banyaknya aspek yang diamati }} \times 100 \%
$$

c. Membandingkan persentase yang didapat dengan kriteria penilaian keterlaksanaan pembelajaran. Kriterian penilaian keterlaksanaan pembelajaran

Welni Julitra Damanik, Edi Syahputra. Pengembangan Perangkat Pembelajaran untuk Menigkatkan Kemampuan Berpikir Kreatif Matematis Siswa Menggunakan Model Discovery Learning. Jurnal Inspiratif, Vol. 4, No. 1 April 2018. 
disajikan pada Tabel 3.5 menurut Khabibah (Yuni, 2010).

Tabel 4. Kriteria Penilaian

Keterlaksanaan Pembelajaran

\begin{tabular}{|c|l|}
\hline Interval Persentase & Klasifikasi \\
\hline$p \geq 85 \%$ & Sangat Baik \\
\hline $70 \%<p \leq 85 \%$ & Baik \\
\hline $50 \%<p \leq 70 \%$ & Cukup \\
\hline$p \leq 50 \%$ & Kurang \\
\hline
\end{tabular}

Menentukan rata-rata persentase untuk keseluruhan pertemuan dan membandingkannya dengan kriteria penilaian keterlaksanaan pembelajaran pada Tabel 3.5. Pembelajaran dikatakan terlaksana jika mencapai kriteria minimal baik

\section{c. Kefektifan}

Keefektifan perangkat pembelajaran diperoleh berdasarkan hasil analisis tes kemampuan berpikir kreatif matematis siswa. Langkah-langkah analisis hasil tes kemampuan berpikir kreatif matematis siswa adalah sebagai berikut:

1) Menentukan skor tiap indikator pada masing-masing butir soal dengan acuan pedoman penskoran yang telah ditetapkan.

2) Menjumlahkan skor tiap indikator kemampuan berpikir kreatif siswa untuk setiap butir soal.

3) Menghitung rata-rata persentase tiap indicator kemampuan berpikir kreatif matematis siswa dengan menggunakan formula:

$$
\begin{aligned}
& r_{i} \\
& \times 100
\end{aligned}
$$

Keterangan :

$$
i=1,2,3,4
$$

4) Mengkonversikan skor tiap indikator yang diperoleh menjadi nilai kualitatif berdasarkan kritaria skala 5 menurut Sudjana (2010:118) seperti pada tabel 3.6 berikut ini:
Tabel 5. Kualifikasi Skor Tes Kemampuan Berpikir Kreatif

\begin{tabular}{|c|l|}
\hline $\begin{array}{l}\text { Persentase Indicator } \\
\text { Kemampuan Berpikir } \\
\text { Kreatif Matematis }\end{array}$ & Kategori \\
\hline$r_{i} \geq 90$ & Sangat Baik \\
\hline $80 \leq r_{i}<90$ & Baik \\
\hline $70 \leq r_{i}<80$ & Cukup \\
\hline $60 \leq r_{i}<70$ & Kurang \\
\hline$r_{i}<60$ & Sangat Kurang \\
\hline
\end{tabular}

Berdasarkan tabel 3.6 di atas dapat diketahui kualifikasi kemampuan berpikir kreatif matematis siswa untuk setiap indikator.

5) Menghitung skor dan menentukan ketuntasan belajar tiap siswa berdasarkan KKM yang telah ditetapkan oleh sekolah yaitu 70 .

6) Menghitung persentase ketuntasan belajar klasikal menggunakan formula: $p=\frac{\text { jumlah siswa yang tuntas }}{\text { jumlah siswa seluruhnya }} \times 100 \%$

Perangkat pembelajaran yang dikembangkan dikatakan efektif jika minimal kualifikasi tingkat keefektifan yang diperoleh adalah $80 \%$.

\section{d. Analisis Peningkatan Kemampuan Berpikir Kreatif Siswa}

Peningkatan kemampuan berpikir kreatif matematis siswa dilihat dari kemampuan berpikir kreatif per indikator secara keseluruhan dari uji coba I dan uji coba II.

\section{a) Analisis Peningkatan kemampuan pemahaman konsep tiap indikator. \\ Berikut merupakan langkah-} langkah analisis peningkatan berpikir kreatif konsep berdasarkan indikator.

1. Menentukan skor tiap indikator pada masing-masing butir soal dengan acuan pedoman penskoran yang telah ditetapkan pada tes berpikir kreatif uji coba I dan uji coba II.

2. Menjumlahkan skor tiap indikator kemampuan berpikir kreatif siswa untuk setiap butir soal pada tes berpikir kreatif uji coba I dan uji coba II.

3. Menghitung persentase pencapaian setiap indikator berpikir kreatif siswa

Welni Julitra Damanik, Edi Syahputra. Pengembangan Perangkat Pembelajaran untuk Menigkatkan Kemampuan Berpikir Kreatif Matematis Siswa Menggunakan Model Discovery Learning. Jurnal Inspiratif, Vol. 4, No. 1 April 2018. 
pada tes berpikir kreatif uji coba I dan uji coba II dengan cara:

$\mathrm{r}_{\mathrm{i}}$

$=\frac{\text { jumlah skor siswa indikator ke }-\mathrm{i}}{\text { jumlah skor maksimal indikator ke }-\mathrm{i}} \times 100 \%$

4. Menghitung rata-rata persentase kemampuan berpikir kreatif siswa setiap indikator dan melihat peningkatannya dari uji coba I ke uji coba II.

b) Analisis Peningkatan Kemampuan berpikir kreatif Secara Keseluruhan

Berikut merupakan langkahlangkah analisis peningkatan kemampuan berpikir kreatif berdasarkan berdasarkan keseluruhan indikator.

1. Menentukan hasil tes kemampuan berpikir kreatif siswa pada uji coba I dan uji coba II berdasarkan pedoman penilaian. Untuk menentukan hasil tes berpikir kreatif dapat dihitung dengan menggunakan rumus (Trianto, 2011: 241) :

$$
\text { SKBK }=\frac{\mathrm{T}}{\mathrm{T}_{\mathrm{t}}} \times 100 \%
$$

Keterangan: $\quad \%$ SKBK $=$ persentase skor kemampuan berpikir kreatif

$\mathrm{T}=$ jumlah skor yang diperoleh siswa

$\mathrm{T}_{\mathrm{t}} \quad=$ jumlah skor total

2. Setelah ditentukan skor tes berpikir kreatif siswa dengan rumus di atas, kemudian menghitung nilai rata-rata kemampuan berpikir kreatif uji coba I dan uji coba II.

3. Melihat peningkatan rata-rata kemampuan berpikir kreatif siswa dari pada uji coba I ke uji coba II.

4. Menentukan banyak siswa untuk setiap tingkat kemampuan berpikir kreatif pada tabel 3.7 berikut dan melihat peningkatannya (Purwanto, 2009: 103).

Tabel 6. Tingkat Kemampuan Berpikir Kreatif

\begin{tabular}{|l|l|}
\hline $\begin{array}{c}\text { Tingkat } \\
\text { Penguasaan }\end{array}$ & \multicolumn{1}{|c|}{ Kategori } \\
\hline $90 \%-100 \%$ & Sangat Tinggi \\
\hline $80 \%-89 \%$ & Tinggi \\
\hline $65 \%-79 \%$ & Sedang \\
\hline $55 \%-64 \%$ & Rendah \\
\hline $0 \%-54 \%$ & Sangat Rendah \\
\hline
\end{tabular}

\section{HASIL PENELITIAN DAN PEMBAHASAN}

Penelitian ini merupakan penelitian pengembangan (development research), sehingga produk dari penelitian ini adalah perangkat pembelajaran berbasis Pendekatan Matematika Realistik. Adapun tujuan pengembangan ini adalah: (1) mendeskripsikan keefektifan perangkat pembelajaran berbasis model pembelajaran discovery learning; (2) mendeskripsikan peningkatan kemampuan berpikir kreatif matematis melalui penggunaan perangkat pembelajaran berbasis model discovery learning dan (3) menemukan perangkat pembelajaran yang efektif dalam meningkatkan kemampuan berpikir matematis siswa.

\section{Kevalidan Perangkat Pembelajaran Berbasis Model Discovery Learning yang Dikembangkan}

Hasil validasi perangkat pembelajaran yang berupa Rencana Pelaksanaan berpikir kreatif Pemahaman Konsep yaitu prestes dan postes, Lembar Peniliaian Pengembangan RPP dan LKS dan Angket Respon Siswa menunjukkan semua instrumen ini tergolong valid. Validitas perangkat pembelajaran yang dikembangkan termasuk dalam kategori valid dengan rata-rata total validitas RPP sebesar 4,02 dan rata-rata total validitas LAS sebesar 4,2.

\section{Keefektifan Perangkat Pembelajaran Berbasis Model Discovery Learning yang Dikembangkan}

Berdasarkan uji coba I dan uji coba II, perangkat pembelajaran model discovery learning yang dikembangkan telah memenuhi kategori efektif ditinjau dari: (1) ketuntasan belajar siswa secara klasikal; (2) ketercapaian indikator/ketuntasan tujuan pembelajaran yang ditetapkan; (3) respon siswa dan guru memberikan respon positif terhadap komponen perangkat pembelajaran yang dikembangkan; dan (4) waktu pembelajaran tidak melebihi pembelajaran biasa.

Welni Julitra Damanik, Edi Syahputra. Pengembangan Perangkat Pembelajaran untuk Menigkatkan Kemampuan Berpikir Kreatif Matematis Siswa Menggunakan Model Discovery Learning. Jurnal Inspiratif, Vol. 4, No. 1 April 2018. 


\section{Pencapaian Ketuntasan Belajar Siswa Secara Klasikal}

Hasil analisis uji coba I pada kemampuan berpikir kreatif matematis diperoleh 18 siswa yang tuntas atau sebesar $60 \%$ pada posttest uji coba I. hasil posttest uji coba I ini belum memenuhi kriteria efektif yang ditetapkan, oleh sebab itu dilakukan uji coba II sebagai proses perbaikan perangkat pemebelajaran. Hasil posttest uji coba II terdapat 26 siswa yang tuntas atau sebesar $87 \%$. Hasil posttest uji coba II ini telah memenuhi kriteria ketercapaian kemampuan berpikir kreatif matematis siswa.

\section{Respon Siswa}

Berdasarkan hasil analisis data respon siswa pada uji coba I dan uji coba II diperoleh kesimpulan bahwa siswa memiliki respon positif terhadap perangkat pembelajaran. Pada uji coba I respon siswa terhadap LAS yang telah digunakan menunjukkan kategori baik dengan skor rata-rata 3,95 dari skor maksimal 5,00. Pada uji coba II diperoleh respon siswa terhadap LAS yang telah digunakan menunjukkan kategori baik dengan skor rata-rata 4,0 dari skor maksimal 5,00. Berdasarkan pencapaian waktu pembelajaran selama uji coba I dan uji coba II, lama waktu pembelajaran menggunakan perangkat pembelajaran berbasis pendekatan matematika realistik sama dengan waktu pembelajaran biasa yang dilakukan selama ini. Waktu yang digunakan dalam pembelajaran uji coba I dan uji coba II adalah lima pertemuan atau 10 x 40 menit. Dengan demikian pembelajaran dikatakan efektif sesuai dengan waktu pembelajaran.

\section{Peningkatan Kemampuan Berpikir Kreatif Matematis Siswa dengan Menggunakan Perangkat Pembelajaran Berbasis Discovery Learning yang Dikembangkan}

Peningkatan kemampuan berpikir kreatif matematis siswa pada uji coba I dan II menunjukkan bahwa rata-rata kemampuan berpikir kreatif matematis siswa pada hasil posttest uji coba I adalah sebesar $70 \%$ meningkat menjadi $81 \%$ pada uji coba II. Hal ini sesuai dengan analisis data peningkatan kemampuan berpikir kreatif matematis dilihat dari rata-rata hasil posttest uji coba I dan uji coba II, dengan demikian diketahui bahwa peningkatan nilai rata-rata kemampuan berpikir kreatif matematis siswa sebesar $11 \%$.

Selanjutnya peningkatan kemampuan berpikir kreatif juga dapat dilihat dari peningkatan tiap indikatornya. Peningkatan tersebut dapat dilihat pada tabel 4.30 berikut ini:

\section{Tabel 7. Rata-rata Peningkatan Kemampuan Berpikir Kreatif} Matematis Siswa untuk Setiap Indikator

\begin{tabular}{|c|c|c|c|}
\hline \multirow{2}{*}{$\begin{array}{c}\text { Indikator } \\
\text { Kemampuan } \\
\text { Berpikir Kreatif } \\
\text { Matematis }\end{array}$} & $\begin{array}{c}\text { Uji } \\
\text { Coba } \\
\text { I }\end{array}$ & $\begin{array}{c}\text { Rata-rata } \\
\text { Coba } \\
\text { II }\end{array}$ & Peningkatan \\
\hline $\begin{array}{l}\text { Keluwesan } \\
\text { (Flexibility) }\end{array}$ & $69 \%$ & $\begin{array}{c}81,5 \\
\%\end{array}$ & $12,5 \%$ \\
\hline $\begin{array}{l}\text { Elaborasi } \\
\text { (Elaboration) }\end{array}$ & $71 \%$ & $80 \%$ & $9 \%$ \\
\hline $\begin{array}{l}\text { Keaslian } \\
\text { (Originality) }\end{array}$ & $77 \%$ & $88 \%$ & $11 \%$ \\
\hline $\begin{array}{l}\text { Kelancaran } \\
\text { (Fluency) }\end{array}$ & $65 \%$ & $77 \%$ & $12 \%$ \\
\hline
\end{tabular}

Berdasarkan Tabel 7 terlihat peningkatan kemampuan berpikir kreatif matematis siswa dari uji coba I ke uji coba II untuk setiap indikator. Pada indikator keluwesan terjadi peningkatan sebesar $12,5 \%$, pada indikator elaborasi terjadi peningkatan $9 \%$, pada indikator keaslian terjadi peningkatan sebesar 11\%, dan pada indikator kelancaran terjadi peningkatan sebesar $12 \%$.

\section{KESIMPULAN}

Berdasarkan hasil analisis dan pembahasan dalam penelitian ini, dikemukakan beberapa kesimpulan sebagai berikut:

1. Validitas perangkat pembelajaran yang dikembangkan termasuk dalam kategori valid dengan rata-rata total validitas RPP sebesar 4,02 dan rata-rata total validitas LAS sebesar 4,2. Perangkat pembelajaran yang dikembangkan melalui model pembelajaran berbasis model

Welni Julitra Damanik, Edi Syahputra. Pengembangan Perangkat Pembelajaran untuk Menigkatkan Kemampuan Berpikir Kreatif Matematis Siswa Menggunakan Model Discovery Learning. Jurnal Inspiratif, Vol. 4, No. 1 April 2018. 
discovery learning juga telah memenuhi kriteria efektif yang ditinjau dari ketuntasan siswa secara klasikal telah tercapai $87 \%$ pada uji coba II, serta perangkat pembelajaran yang dikembangkan telah memenuhi kriteria praktis ditinjau dari angket respon siswa terhadap perangkat pembelajaran yang dikembangkan sudah memenuhi kriteria yang ditentukan yakni "Baik".

2. Peningkatan kemampuan berpikir kreatif matematis siswa menggunakan perangkat pembelajaran berbasis discovery learning pada materi bangun datar segiempat adalah rata-rata pencapaian kemampuan berpikir kreatif matematis siswa pada uji coba I sebesar 68 meningkat menjadi 79 pada uji coba II. Di samping itu, rata-rata setiap indikator kemampuan berpikir kreatif matematis siswa meningkat dari uji coba I ke uji coba II.

\section{SARAN}

1. Perangkat pembelajaran berbasis model discovery learning yang dikembangkan telah memenuhi aspek keefektivan, kepraktisan dan valid, maka disarankan kepada guru untuk dapat menggunakan perangkat pembelajaran ini guna meningkatkan kemampuan berpikir kreatif matematis siswa khususnya siswa kelas VII SMP.

2. Bagi peneliti lain yang hendak melakukan penelitian untuk mengukur kemampuan berpikir kreatif agar lebih memperhatikan kemampuan siswa pada setiap indikator berpikir kreatif khususnya pada indikator kelancaran (fluency) karena pada penelitian ini baik uji coba I maupun II yang paling rendah dari semua indikator adalah indikator kelancaran (fluency

\section{DAFTAR PUSTAKA}

Asari, Tohir, Valentino, Imron, Taufiq., (2016), Matematika: Buku Guru. Kemendikbud, Jakarta

Asari, Tohir, Valentino, Imron, Taufiq., (2016), Matematika: Buku Siswa. Kemendikbud, Jakarta
Aufa, M., dkk., (2016), Development Of Learning Devices Trought Problem Based Learning Model Based On Context Of Aceh The Cultural Improve Mathematical Communication Skill And Social Skills of SMPN 1 Muara Batu Students, Journal of Education and Practice 5 (39)

Balm, A., (2009), The Effects Of Discovery Learning On Students' Success And Inquiry Learning Skill, Egitim ArastirmalaruEurasian Journal of Educational Research, $35: 1-20$

Cahyani,U.A., (2014), Pengembangan Perangkat Pembelajaran

Matematika dengan Pendekatan

Penemuan Terbimbing (Guided

Discovery Learning) Materi

Prisma dan Limas untuk Siswa Kelas VIII Semaester II.,Skripsi,FMIPA,UNY, Yogyakarta

Chaerani, dkk., (2015), Problem Based Learning Buginese Cultural Knowledge Model Case Study: Teaching Mathematics at Junior High School, International education studies 08 (04)

Dahar,W.R., (2011), Teori-teori Belajar dan Pembelajaran, Erlangga, Jakarta

Daryanto dan Dwicahyono., (2014), Pengembangan Perangkat Pembelajaran Silabus, RPP, PHB, Bahan Ajar, Gava Media, Yogyakarta

Dimiyati dan Mudjiono., (2013), Belajar dan Pembelajaran, Rineka Cipta, Jakarta

Euphony, (2010), The Effectiveness Of Inductive Discovery Learning In 1:1 Mathematics Classroom, Proceedings of The $18^{\text {th }}$ International Conference On Computers In Education, Malaysia, 743-747

Welni Julitra Damanik, Edi Syahputra. Pengembangan Perangkat Pembelajaran untuk Menigkatkan Kemampuan Berpikir Kreatif Matematis Siswa Menggunakan Model Discovery Learning. Jurnal Inspiratif, Vol. 4, No. 1 April 2018. 
Fathurohman, M., (2015), Model-model Pembelajaran Inovatif Alternatif Desain Pembelajaran yang Menyenangkan, Ar-ruzz Media, Yogjakarta

Gita, K.M., (2013), Pengembangan Perangkat Pembelajaran Matematika Berbasis discovery Learning Pada Pokok Bahasan Teorema Phytagoras Di Kelas VII SMP. Jurnal Kadikma, 04 (03)

Ismayati dan Nurlaela., (2015), Strategi Belajar Berpikir Kreatif, Ombak, Yogyakarta

Jumadi, (2013), Penerapan Pembelajaran Penemuan Terbimbing Untuk Meningkatkan Hasil Belajar Matematika Siswa Kelas VII SMP Negeri 9 Malang. Program Studi Pendidikan Matematika. Universitas Negeri Malang.

Marliani, N., (2015), Peningkatan Kemampuan Berpikir Kreatif Matematis Siswa melalui Model Pembelajaran Missouri Mathematics Project (MMP), Jurnal Formatif 5 (1)

Mawaddah, Kartono, Suyitno., (2015), Model Pembelajaran Discovery Learning dengan Pendekatan Metakognitif untuk Meningkatkan Metakognisi dan Kemampuan Berpikir Kreatif Matematis, Unnes Journal of Mathematics education research 4 (1) : 1-8

Moma, L., (2015), Pengembangan Instrumen Kemampuan Berpikir Kreatif Matematis Untuk Siswa SMP, Jurnal Matematika dan Pendidikan Matematika

Mubarok dan Sulistyo., (2014), Penerapan Model Pembelajaran Discovery Learning Terhadap Hasil Belajar Siswa Kelas X TAV pada Standar Kompetensi Melakukan Instalasi Sound System di SMK Negeri 2 Surabaya, Jurnal Pendidikan Teknik Elektro 03 (1) : 215-221
Muhammad, N., (2015), Pengaruh model discovery learning untuk meningkatkan kemampuan representasi matematis dan percaya diri siswa, Jurnal Pendidikan Universtas Garut 09 (01) : 75-90

Nieven. N., (2007), Education Design Research, Netherland, Colophon

Nurharini dan Wahyuni., (2008), Matematika Konsep dan Aplikasinya, Pusat Penerbit Departemen Pendidikan Nasional, Jakarta

Putra, Irwan, Vionanda., (2012), Meningkatkan Berpikir Kreatif Siswa dengan Pembelajran Berbasis Masalah, Jurnal Pendidikan Matematika, Vol. 1 (1): $22-26$

Putrayasa, Syahruddin, Margunayasa., (2014), Pengaruh Model Pembelajaran Discovery Learning dan Minat Belajar terhadap Hasil Belajar Siswa, Jurnal Mimbar PGSD Universitas Pendidikan Ganesha 2 (1)

Riani, Surya, Syahputra., (2015), Perbedaan Peninkatan Berpikir Kreatif Matematis dan Kemamdirian Siswa pada Pembelajaran Berbasis Masalah dan Pembelajaran Konvensional di SMPN 4 Padang Sidempuan, Jurnal Paradikma 8 (3)

Rochmad, 2012, Desain Model Pengembangan Perangkat Pembelajaran, Jurnal Kreano, 3 (1) : 59-72

Rudiyanto, (2014), Pengembangan Perangkat Pembelajaran Model Discovery Learning dengan pendekatan saintifik bermuatan karakter untuk meningkatkan kemampuan berpikir kreatif, Premiere Educandum 4(1):44-48

Welni Julitra Damanik, Edi Syahputra. Pengembangan Perangkat Pembelajaran untuk Menigkatkan Kemampuan Berpikir Kreatif Matematis Siswa Menggunakan Model Discovery Learning. Jurnal Inspiratif, Vol. 4, No. 1 April 2018. 
Sani, R., (2014), Pembelajaran Saintifik untuk Implementasi Kurikulum 2013, PT Bumi Aksara, Jakarta

Sani, R., (2013), Inovasi Pembelajaran, PT Bumi Aksara, Jakarta

Sinaga, B., (2007), Pengembangan Model Pembelajaran Matematika Berdasarkan Masalah Berbasis Budaya Batak (PBM-B3). Disertasi tidak Dipublikasikan. Surabaya. PPs Unesa

Sudjana,N., (2010), Penilaian Hasil Proses Belajar Mengajar, PT Remaja Rosdakarya, Bandung

Sugiyono, (2015), Metode Penelitian dan Pengembangan Research and Development, Alfabeta, Bandung

Sugiyono, (2015), Metode Penelitian Pendidikan: Pendekatan Kuantitatif, Kualitatif dan R\&D, Alfabeta, Bandung

Surya E. 2013. Analisis Pemetaan dan Pengembangan Model Pembelajaran Matematika SMA di Kabupaten Tapteng dan Kota Sibolga Sumatera Utara. Jurnal Pendidikan Matematika PARADIKMA, Vol 6 Nomor 1, hal 75-88.

Surya, E. Putri, F.A. and Mukhtar. 2017. Improving Mahematical Problem Solving Ability and SelfConfidence of High School Students Through Contextual Learning Model. Indonesian Mathematical Society Journal on Mathematics Education, 8(1), 8594.

Surya, E. and Syahputra, E. 2017. Improving High-Level Thinking Skills by Development of Learning PBL Approach on The Learning Mathematics for Senior High School Students. International Education Studies, 10(8), 12-20.
Syah, M., (2010), Psikologi Pendidikan, PT Remaja Rosdakarya, Bandung

Syahbana, A., (2012). Pengembangan Perangkat Pembelajaran Berbasis Kontekstual untuk Mengukur Kemampuan Berpikir Kritis Matematis Siswa SMP. Edumatica 02 (02) : 17-26

Thiagarajan, S. Semmel, D.S \& Semmel,M.I., (1974), Instructional Development for Training Teachers of Exceptional Children, Indiana University.

Trianto, (2010), Mendesain Model Pembelajaran Iovatif-Progresif: Konsep, Landasan, dan Implementasinya pada Kurikulum Satuan Tingkat Pendidikan, Kencana, Jakarta

Tomi,dkk., (2012), Meningkatkan Kemampuan Berpikir Kreatif dengan Pembelajaran Berbasis Masalah, Jurnal Pendidikan Matematika 1 (1):22-26

Widoyoko, E.P., (2009), Evaluasi Program Pembelajaran: Panduan Praktis bagi Pendidik dan Calon Pendidik, Pustaka Pelajar, Yogyakarta

Yuliani dan Saragih., (2015), The development of Learning Devices Based Guided Discovery Learning Model to Improve Understanding Concept and Critical Thingking Mathematically Ability of Student at Islamic Junior High School of Medan, Journal of Education and Pratice 6 (24)

Welni Julitra Damanik, Edi Syahputra. Pengembangan Perangkat Pembelajaran untuk Menigkatkan Kemampuan Berpikir Kreatif Matematis Siswa Menggunakan Model Discovery Learning. Jurnal Inspiratif, Vol. 4, No. 1 April 2018. 